\title{
Artículo especial: La comunicación de malas noticias: comentarios complementarios
}

\author{
The communication of bad news: complementary comments
}

Carlos Musso*

\section{Resumen}

El autor discute sobre algunos aspectos de la comunicación de malas noticias en la práctica clínica. Rescata que debe implicar el compromiso de ayudar al receptor del mensaje a transitar el camino que tendrá por delante, a no mentirle pero tampoco a someterlo a un "encarnizamiento informativo", evitando que escuche información para la que todavía pueda no estar preparado; y eventualmente, aceptando los mecanismos de defensa que pueda poner en juego para aliviar el dolor ante dicha situación.

\section{Abstract}

The author discusses some aspects of the communication of bad news in clinical practice. He emphasizes it should imply a commitment to help the receiver of the message get through the road ahead; one should neither lie nor undertake an information overload strategy, so the receiver may avoid listening to information he might not be ready for, and eventually accept the defence mechanisms he can bring into play to relieve the pain at a specific situation.
\end{abstract}

Musso C. La comunicación de malas noticias: comentarios complementarios. Evid Act Pract Ambul. 12(3): 118, Jul-Sep.2009.

Luego de haber leído y disfrutado el articulo de la Dra Gabriela Buela ${ }^{1}$ sobre "la comunicación de malas noticias", y coincidiendo con los conceptos vertidos por ella, así como con su visión respecto de la importancia que tiene el aprendizaje y ejercicio de este tema en la tarea médica cotidiana, creí de utilidad compartir algunas consideraciones complementarias.

Si bien no existe una fórmula mágica para comunicar malas noticias, -hay en realidad tantas formas de hacerlo como interlocutores y situaciones complejas-, sí existen lineamientos generales que pueden contribuir a facilitar dicha tarea ${ }^{2}$.

El primero y principal de estos lineamientos es el concepto de que dar una mala noticia implica un compromiso previo de ayudar al receptor de la misma a transitar el difícil camino que se abre frente a él ${ }^{3}$. Es entonces por esta razón, que debe siempre acompañarse un informe de este tipo con el ofrecimiento de un plan para su resolución, retraso evolutivo o alivio sintomático, según corresponda. Debe desterrarse definitivamente del discurso médico la nefasta frase "...no hay nada más para hacer...", no sólo porque desalienta terriblemente al paciente, sino porque además no es cierta, ya que "...siempre hay algo para hacer..." en su beneficio en alguno de los múltiples planos terapéuticos existentes.

Otro aspecto clave consiste en no mentirle nunca al paciente. Primero, porque la relación médico-paciente se basa en la confianza, y una mentira dicha por el médico y descubierta por el paciente quiebra irremediablemente dicha relación. Lo contrario de una verdad cruel no es una mentira piadosa, si no una verdad adecuadamente revelada, ya que aquello que es cruel no es la verdad sino la forma en la que se la ha planteado.

Además, la verdad es el mejor antídoto contra el miedo, ya que para el enfermo es mucho menos penoso estar al corriente de la situación que quedar en el desconocimiento sospechando lo peor, pues la incertidumbre de lo ignorado engendra monstruos ${ }^{4}$.

Ahora bien, así como el paciente tiene derecho a saber su situación y el médico tiene el deber de informársela, al paciente también le asiste el derecho a renunciar a saber que es lo que le pasa. Debe recordarse que una cosa es mentir y otra muy distinta, no decir una verdad cuando el paciente expresamente no desear saberla. El no respetar esta voluntad no es más que un "encarnizamiento informativo". Por otra parte, de haberse detectado que el paciente desea ser informado, debe entonces averiguarse con que profundidad desea serlo, pues tal vez simplemente solicite saber cuanto puede afectarlo su problema y en que forma, sin que sea necesario "intoxicarlo" con una jerga médica inconducente.

La actitud del médico al momento de comunicar debe ser relajada, mostrándose abocado a ello, dejando inicialmente que el paciente se explaye -lo que permite evaluar cuanto sabe y cuanto quiere enterarse del problema- para luego expresarse mediante un discurso simple y utilizando palabras cuya carga emocional negativa (palabras malsonantes) no sea más que la estrictamente necesaria.

Si durante el diálogo con el paciente el médico se topase con cualquiera de las formas de la negación (racionalización, minimización, desplazamiento, etc.) todos ellos mecanismos psicológicos mediante los cuales el paciente trata de defenderse de una realidad dolorosa y aferrándose a la imagen de una realidad previa, no debe intentarse quebrar dicha negación, ya que su presencia implica que el paciente no está preparado para registrar la verdad. Es mucho mejor reintentar comunicar aquello que se necesite más adelante cuando dicho mecanismo de defensa se haya disipado, o por lo menos reducido en intensidad.

\section{Conclusión}

Comunicar malas noticias es una tarea compleja de la medicina asistencial, para la cual nunca se está suficientemente preparado, razón por la cual deben multiplicarse las instancias que propicien su aprendizaje ${ }^{5}$.

Referencias

1. Buela G. La comunicación de malas noticias. Evid Act Pract Ambul. 11(5): XX-XX-Sep-Oct.2008. Disponible en URL: http://www.foroaps.org/files/mala\%20noticia.pdf

2. Comunicación de malas noticias en el proceso de atención médica. En Boletín del Consejo Académico de Ética en Medicina (CAEEM). $2004: 107-111$.

3. Gómez Sancho M. Como dar las malas noticias en medicina. Madrid. Arán. 2006.

4. Musso C y col. Semiótica Médica: principios lingüísticos y comunicacionales de uso médico. Buenos Aires. delhospital ediciones. 2007.

5. Musso C. La crisis de la medicina moderna: más allá de la medicina del cuerpo. En Boletín del Consejo Académico de Ética en Medicina (CAEEM). $2004:$ 99-106.

* Servicio de Nefrología, Hospital Italiano de Buenos Aires. carlos.musso@ @ospitalitaliano.org.ar 